Int. J. Dev. Biol. 48: 293-305 (2004)

Original Article

\title{
Molecular markers for germ cell differentiation in the demosponge Suberites domuncula
}

\author{
SANJA PEROVIĆ-OTTSTADT ${ }^{1}$, HELENA ĆETKOVIĆ ${ }^{2}$, VERA GAMULIN ${ }^{2}$, HEINZ C. SCHRÖDER ${ }^{1}$, KLAUS KROPF ${ }^{1}$, \\ CLAIRE MOSS ${ }^{3}$, MICHAEL KORZHEV ${ }^{1}$, BÄRBEL DIEHL-SEIFERT ${ }^{1}$, ISABEL M. MÜLLER ${ }^{1}$ \\ and WERNER E.G. MÜLLER*,1 \\ ${ }^{1}$ Institut für Physiologische Chemie, Abteilung Angewandte Molekularbiologie, Universität, Mainz, Germany, \\ ${ }^{2}$ Department of Molecular Biology, Ruder Boskovic Institute, Zagreb, Croatia and \\ ${ }^{3}$ Scottish Association for Marine Science, Dunstaffnage Marine Laboratory, Oban, Argyll. UK.
}

\begin{abstract}
Sponges (phylum Porifera) are simple metazoans for which no molecular information on gametogenesis and larval development is available. To support the current study, it was confirmed by histology that oocytes and larvae were produced by the demosponge Suberites domuncula. Three genes/expressed products from $S$. domuncula whose expression correlated with sexual reproduction were identified and characterized (they are used here as marker genes): i) a receptor tyrosine kinase (RTK) with sequence similarity in the tyrosine kinase domain to fibroblast growth factor receptors; ii) the sex-determining protein FEM1 and iii) the sperm associated antigen (SAA) of triploblasts. Antibodies against the extracellular domain of the RTK specifically stained oocytes and larvae in $S$. domuncula tissue sections. Induction of these three genes was successful at elevated temperature, a factor which also promotes natural gametogenesis. In situ hybridization analyses revealed that FEM1 and SAA were expressed in those areas in which gametogenesis begins. Our results indicate that genes which play a role in sex determination may be present in Porifera.
\end{abstract}

KEY WORDS: FEM1, gametogenesis, larva, sponge, Suberites domuncula, sperm associated antigen

\section{Introduction}

Sponges [phylum Porifera] are subdivided into three classes, Hexactinellida, Demospongiae and Calcarea. Molecular sequence data has established that the Calcarea are the sister group to higher metazoan phyla, while the other two classes branched off from the common metazoan ancestor, the Urmetazoa, as the phylogenetically earliest taxon (Müller et al., 1998; Müller, 2001; Müller etal., 2001). Porifera are considered to lack organs, muscles or a nerve cell system; nevertheless they are composed of differentiated cells that originate from stem cells and comprise structural and functional elements to establish a defined body plan (Müller et al., 2003a; reviewed in: Müller et al., 2004). The sponge body is surrounded by an epithelium that encompasses a mesogleal compartment, the mesohyl; this is reticulated in a highly organized manner by a canal system and these canals are also lined by the epithelium. The epithelial layer is formed by several types of pinacocyte cells; (i) those which constitute the external epithelium, the exopinacoderm, are termed exopinacocytes, (ii) the cells which allow the attachment to the substratum, are the basopinacocytes that form the basopinacoderm and (iii) those which form the aquiferous canals are the endopinacocytes of the endopinacoderm. All cells are associated with each other by a highly complex cell-cell adhesion system (see: Müller, 1982; Müller et al., 1988; Blumbach et al., 1998; Schütze et al., 2001) and in some sponge species they are additionally connected by cell junctions (see: Simpson, 1984; Adell et al., 2004). To date only cytological markers have allowed a description of the differentiation pathways of sponge cells (Boury-Esnault and Rützler, 1997); molecular markers are only available for the sclerocytes (= skeletal cells) (Müller et al., 2003a and 2003b; Müller et al., 2004). Conse-

Abbreviations used in this paper: RTK, receptor tyrosine kinase; SAA, sperm associated antigen.

*Address correspondence to: Dr. Werner E.G. Müller. Institut für Physiologische Chemie, Abteilung Angewandte Molekularbiologie, Universität, Duesbergweg 6, 55099 Mainz, Germany. Fax: +49-6131-392-5243. e-mail: wmueller@uni-mainz.de

Accession Numbers: Sequences from Suberites domuncula have been deposited in EMBL/GenBank with the indicated accession numbers: 18S and 28S rRNA genes (AJ620112 and AJ620113 respectively), the receptor tyrosine kinase RTKvs_SUBDO (AJ620110), the FEM1-like protein FEM1L_SUBDO (AJ620109) and the sperm associated antigen-related protein (AJ620111). 


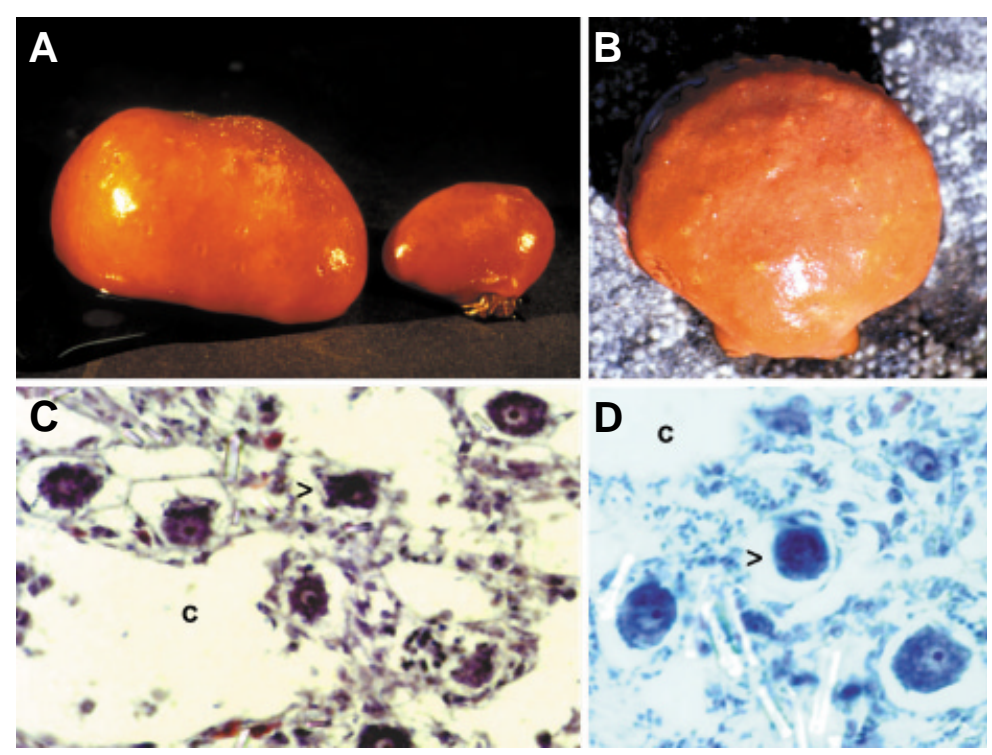

Fig. 1. Suberites domuncula and oocytes. The different morphotypes (A) S. domuncula from the Adriatic Sea growing with the hermit crab (Pagurites oculatus) residing in a shell of the mollusk (Trunculariopsis trunculus). (B) A specimen from the west of Scotland encrusting the bivalve Chlamys opercularis. (C,D) Cross sections through an animal collected during early summer showing the oocytes (arrow head) adjacent to the aquiferous canals (c). Staining was performed with haematoxylin and eosin. Magnifications: (A) x1; (B) x0.5; (C) x40; (D) x60.

quently, it remains uncertain which cell type(s) is the totipotent one from which the other differentiated cells derive. At present, motile archaeocytes in the mesohyl are considered totipotent (see: Simpson, 1984) and it has been proposed that the germ cells derive from these totipotent archaeocytes (reviewed in: Müller et al., 2004). The germ cells must then undergo a reduction of chromosome number by half during gamete formation, in order to reinstate the diploid chromosome number during fertilization. To the best of our knowledge this process of meiosis has not yet been described in sponges. Therefore, it is not surprising that the differentiation stages starting from the archaeocytes are still under discussion (see: Simpson, 1984; Witte and Barthel, 1994). While Borojevic (1966) presented evidence that the differentiated pinacocytes and choanocytes are probably terminally differentiated, it has, in contrast, been hypothesized that choanocytes are still able to develop into polyblasts from which again archaeocytes can differentiate (Connes etal., 1974). Thus sponge cell lineages, especially those involved in development and reproduction, are only poorly understood. Sponges do not have specialized reproductive organs so germ cells are likely to be located throughout the animal. In the freshwater species Spongilla lacustris germ cells are known to differentiate from archaeocytes either directly, as in the case of the oocytes, or via the choanocyte stage, as for the spermatocytes (Paulus, 1989). A similar genesis has been described for the marine demosponge Halichondria panicea (Barthel and Detmer, 1990; Witte and Barthel, 1994). It also remains basically unknown whether sponges are gonochoric, hermaphroditic or both, in parallel or successively. It is, however, firmly established that sponges reproduce both asexually, via gemmules and sexually through germ cells (reviewed in: Simpson,
1984). The latter results in the formation of larvae which have been grouped into four general morphological categories (see: Leys, 2003); amphiblastula, coeloblastula, parenchymella and trichimella, the latter being characteristic for hexactinellid sponges. Again, this classification should not be considered as definitive since most descriptions rely on static images obtained at various, uncertain stages (Leys, 2003). Specific molecular probes characteristic for germ/larval cells in the sponge system, which would help to determine cell lineages, have not yet been described.

The aim of the present study was to identify molecular probes which could be used to study sponge development and differentiation, using the demosponge Suberites domuncula as a model species. Indeed, the first study on gametogenesis in $\mathcal{S}$. domuncula was by Carter (1883) who demonstrated that oocytes and spermatogenic cysts are present in the tissue. We used antibodies raised against the extracellular domain of a receptor tyrosine kinase (RTK) from $\mathcal{S}$. domuncula [termed RTKvs_SUBDO], which displays no remarkable sequence similarity to any protein present in the databases. In the intracellular region this sequence has similarity to fibroblast growth factor receptors (FGFR), which are known to be involved in developmental and differentiation processes (Ornitz and Itoh, 2001). Histological studies with the RTKvs_SUBDO antibodies provided the first marker to specifically recognize sponge oocytes and larvae. In our search for further tools to identify specific genes involved in sponge gametogenesis and/or embryogenesis we selected two further cDNAs from the $S$ domunculaEST database (http://spongebase.genoserv.de/). The first is a member of the FEM1 (feminization gene) family (VenturaHolman et al., 1998), a molecule which acts in Caenorhabditis elegans as a component of the signal transduction pathway controlling sex differentiation (Kimble et al., 1984; reviewed in: Reinke et al., 2000) and is also highly expressed in mammalian systems (Ventura-Holman et al., 2003). The second cDNA encodes the sperm associated antigen $(S A A)$, which is a marker protein of spermatogenesis in mammals (Beaton et al., 1994). These elaborated molecular tools, the antibodies against $\mathcal{S}$. domunculaRTK/FGFR and the genes $R T K$, FEM1 and $S A A$, were applied together in an attempt to gain the first insights into gametogenesis and larval development in sponges.

\section{Results}

\section{The sponge species Suberites domuncula and its oocytes}

$S$. domuncula was first described as Alcyonium ficus (Pallas, 1766) and/or as Alcyonium (Suberites) domuncula (Olivi, 1792). At present, this taxon is systematically subdivided into $\mathcal{S}$. domuncula (Olivi, 1792) and $\mathcal{S}$. ficus (Johnston, 1842) The prominent difference between these two "species" are their growth forms; $S$. domuncula grows commensally with a hermit crab (Pagurites oculatus [Decapoda: Paguridea], which resides predominantly in shells of the mollusk Trunculariopsis trunculus [Gastropoda: Muricidae]) (Fig. 1A), while $\mathcal{S}$. ficus can be found encrusting the bivalve Chlamys opercularis (Fig. 1B), or in other massive forms. Burton considered the two assumed species as the same taxon (Burton, 1953). Since morphological characteristics, primarily the spicules, are not sufficient for species discrimi- 
A

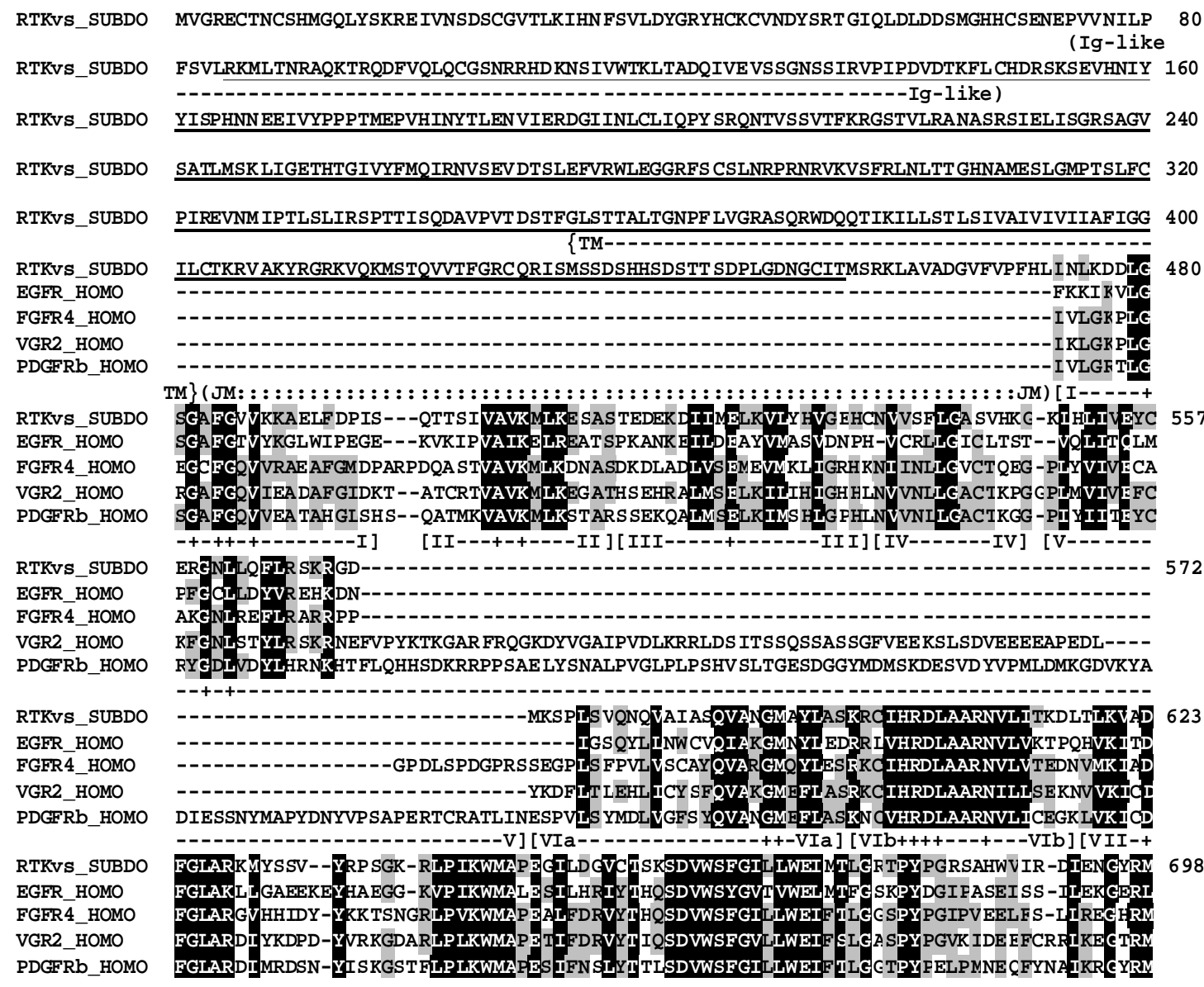

RTKvs_SUBDO EGER_HOMO FGER4_HOMO VGR2_HOMO PDGF Rb_HOMO

RTKvs_SUBDO EGER_HOMO FGER4_HOMO VGR2_HOMO PDGE'Rb_HOMO

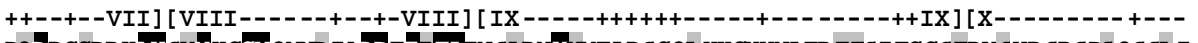

PQPDGCPDKLY SVMKCCWOMNP IARPEFTELTN SLDNVVME LDSGQL HKCYYNLED TTS I EGCSTDV SYRSRSPS QSSL I 778 PQP P ICT IDVYMI MVKCWMI DADSRPKF REI I IEFS KMARDPQRYLV IQGDERMHLP SP TDSNFYRALNDE EDMDDVVDA DRP P HCP P ELYGL MRECWHAAP SQRP TT KOLVEALDKVLLAVSEEY IDLRLTF GPYSP S GGDASS TCSSSDSVF SHDFIP RAP DYTT PEYY TMLDCWHGEP SORPTTSELVEHLGNLL OANAQQDG KDYIVLP ISETLSMEED SGL SIPT SPVS CMEEE AQP AHAS DEI YEI MQKCWEEKFE I RP P S S QLV LILE FLL GEGYKKKY QQVDEEF LR SDHPAILRSQARLP GFHGLRSPLD $--+\mathrm{X}][\mathrm{XI}-$

SHMYCSYCQPVS NHTS LNRTSPP LGSSSFPFGSGVQT

EVCDPKF HYDNT AGIS QYLQNTSSVLY KRKS RPVSVKTFEDIPLEEP EVKVIPDDNQTDSGMVLASE
$--T A V O P N E G D N D Y I$ IPLPDPKPEVADEGPLEGSPSLASS DEYLIPQQGFFS SP ST SRTPLLS SLSATSNNSTVACIDRNGLQS CP IKEDSFLQRYSSDP TGALTEDSIDDTFLPVPEYI
B

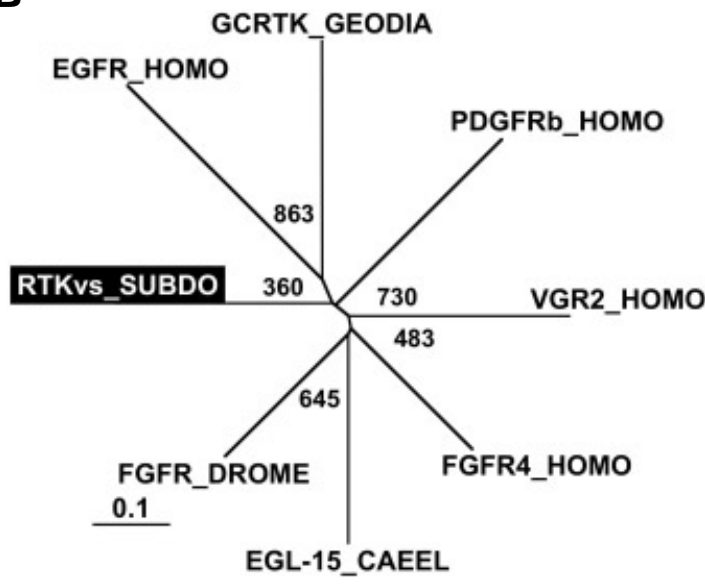
tors: the epidermal growth factor receptor precursor [receptor protein-tyrosine kinase ErbB1] (EGFR_HOMO, P00533), the platelet-derived growth factor receptor beta precursor [beta] (PDGFRb_HOMO, NP_002600.1) and the vascular endothelial growth factor receptor 2 precursor (VGR2_HOMO, P35968). The protein sequence RTKVs_SUBDO comprises an extracellular region, a transmembrane part (TM), the juxtamembrane region (JM) and the intracellular TK domain (subdomains I to XII). In the extracellular region one very distantly related immunoglobulin-like (lg-like) domain can be traced ( $\left(a a_{74}\right.$ to aa ${ }_{148}$. Within the TK domain the 12 characteristic subdomains (in roman letters) are delimited; the conserved aa residues are marked (+). Residues conserved (similar or related with respect to their physico-chemical properties) in all sequences are shown in white on black and those in at least three sequences in black on gray. The extracellular part of RTKvs_SUBDO was prepared recombinantly in E. coli (underlined). The human sequences were truncated, only the central TK domains are shown. (B) These five sequences are compared with the fibroblast growth factor receptor from Drosophilamelanogaster (FGFR_DROME, BAA03617.1), the FGFREGL-15 from Caenorhabditis elegans (EGL-15_CAEEL, AAP44084.1) and the sponge [Geodia cydonium] receptor tyrosine kinase (GCRTK_GEODIA,CAA51198.1). The tree was computed. Scale bar indicates an evolutionary distance of 0.1 aa substitutions per position in the sequence. 
Fig. 3. Detection of oocytes and larvae in $\boldsymbol{S}$. domuncula. The antibodies PoAb-RTKvs were used to stain a cross section through one specimen collected in May (in the Rovinj area). (A) The oocytes (marked with an arrowhead) are detected with the antibodies, while the surrounding cells, also including the follicle epithelium which forms a cavity around the oocytes and later around the larvae, remained unstained. The small hollow structures which have formed after dissolving the spicules also react with these antibodies. Some canals which are located in the vicinity of the oocytes are marked (C). (B,C) Mature oocytes with prominent nuclei. (D) Morula stage of an embryo as well as (E) a developing and $(\mathbf{F})$ a mature coeloblastula is shown. Immunohistochemical analysis was performed as described under "Materials and Methods". Magnifications: $(A, B) \times 20$; $(C) \times 120$; $(D-F) \times 220$.
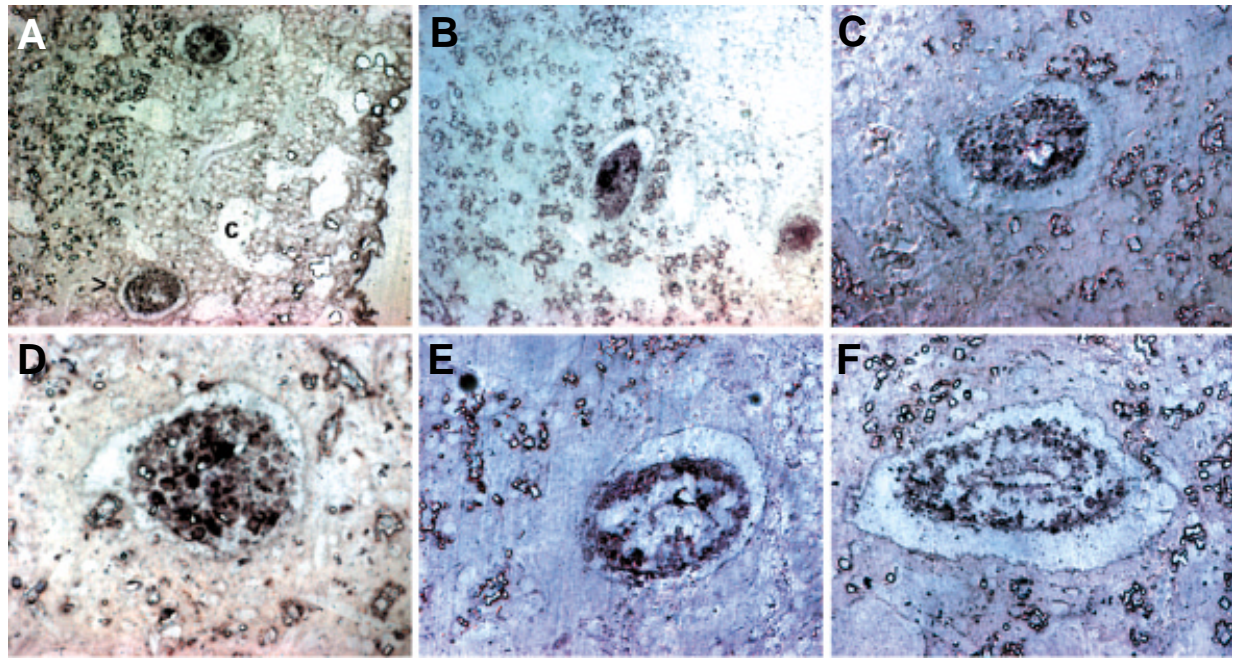

nation we applied rRNA sequence analysis, to enable us to incorporate both 'species' into our analysis. It was found that no nt exchanges exist in the 18S rRNA/SSU between the supposed $\mathcal{S}$. domuncula and $\mathcal{S}$. ficus specimens. Likewise no significant differences were identified in the 28S rRNA/LSU sequence, as described under "Materials and Methods". Therefore, we follow the view of Burton (1953) and unify $\mathcal{S}$. domuncula and $S$ ficus as Suberites domuncula sensuBurton, 1953 and have used material from both locations described in this study. Cross sections through $S$. ficuscollected in early summer (May/June), the season for the production of gametes and larvae (Diaz, 1973), show what appear to be numerous oocytes and occasionally developing larvae (Fig. $1 \mathrm{C}, \mathrm{D})$. If these are indeed reproductive bodies, then they are present in large numbers, especially adjacent to the aquiferous canals. The sizes of the oocytes or developing larvae are between 80 and $130 \mu \mathrm{m}$, matching those described for $\mathcal{S}$. massa (Diaz, 1973).

\section{Receptor tyrosine kinase SDRTKvs}

The cDNA SDRTKVS encoding the receptor tyrosine kinase RTKvs_SUBDO with a length of $3516 \mathrm{nt}$, comprises the ORF from

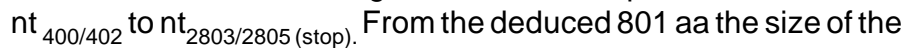
protein was predicted as $89,431 \mathrm{Da}$. The protein sequence comprises, as all the other RTKs, an extracellular region $\left(\mathrm{aa}_{1}\right.$ to $\left.\mathrm{aa}_{352}\right)$, a transmembrane part $\left(\mathrm{aa}_{353}\right.$ to $\left.\mathrm{aa}_{402}\right)$, a juxtamembrane region $\left(\mathrm{aa}_{403}\right.$ to $\left.\mathrm{aa}_{472}\right)$, the intracellular TK domain $\left(\mathrm{aa}_{473}\right.$ to $\left.\mathrm{aa}_{733}\right)$ and a serine rich region at the C-terminus (Fig. 2A). The highest sequence similarity of the characteristic intracellular TK domain from $\mathcal{S}$. domuncula is to the fibroblast growth factor receptors 4 (FGFR4) listed in the databases. Until now no RTK protein comprising high sequence similarity to FGFRs has been described from sponges (Schäcke et al., 1994; Ono et al., 1999; Suga et al., 2001). Since the data presented here suggest a correlation with the sex-determination of selected cells, we termed the deduced protein SDRTK $v s$ and coding for RTKvs_SUBDO [v: variant; s: sex-determination specific].

The extracellular part of the RTKvs_SUBDO shows no obvious similarity to any other (deduced) protein submitted to the databases. Therefore, this part of the protein can currently be considered to be sponge-specific. Usually the metazoan FGFRs, especially those from group-4, comprise immunoglobulin-like (Ig-like) domains in the extracellular regions (Hardie and Hanks, 1995). Motif scan analysis of the sponge extracellular domain with the Isrec-Server (2003) revealed a non-significant similarity to lg-like domains with an expected value $E=2.1 \mathrm{e}+2$ between $\mathrm{aa}_{74}$ to $\mathrm{aa}_{148}$ (Fig. 2A). The intracellular TK domain, however, possesses the 12 characteristic subdomains (Hanks and Quinn, 1991; Hardie and Hanks, 1995). Without exception all conserved aa residues found in TK domains of other fibroblast growth factor receptors are present in the sponge sequence (Fig. 2A).

A

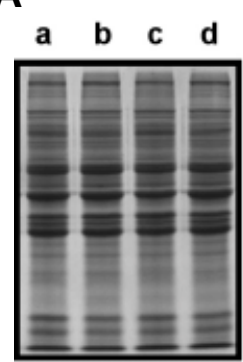

$\begin{array}{llll}1 / 2 & 5 / 6 & 7 / 8 & 9\end{array}$
B

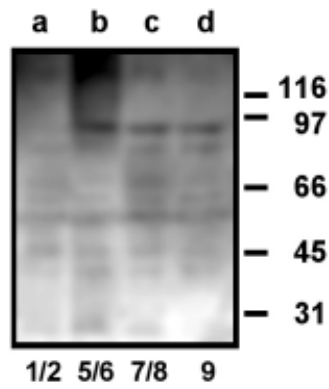

C relative intensities

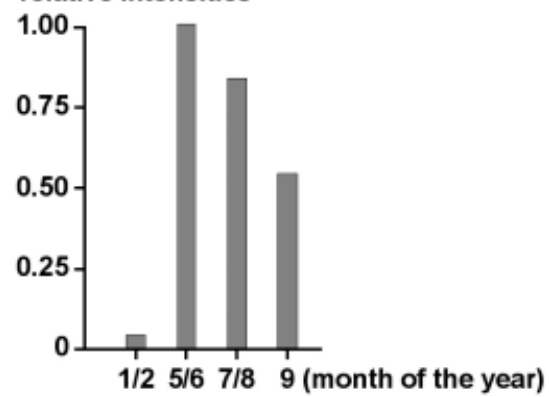

Fig. 4. Level of protein expression of the $S$. domuncula RTK, RTKvs_SUBDO. Specimens were collected in different months during the year; lanes (a) January/February (1/2); (b) May/ June (5/6); (c) July/August (7/8) and (d) September (9). $20 \mu \mathrm{g}$ of protein per lane were subjected for analysis by PAGE. (A) The gel was stained with Coomassie brilliant blue, or (B) the proteins were blot transferred and reacted with PoAb-RTKvs. Detection of the immunocomplex was carried out as described under "Materials

and Methods". The $90 \mathrm{kDa}$ band, corresponding to the sponge RTK, is marked. (C) The intensities of the bands were quantified, as described under "Materials and Methods". The relative degree of expression is given and correlated with that seen for the maximal expression (during May/June). 


\section{Phylogenetic analysis}

As known from previous studies, RTKs occur in metazoans from sponges to the crown species, but are absent in yeast and plants (Schäcke et al., 1994; Müller and Schäcke, 1996). Sequence alignment shows that the sponge RTKvs_SUBDO lacks an insert in the TK domain, that is characteristic for fibroblast growth factor receptors, platelet-derived growth factor receptors as well as for vascular endothelial growth factor receptors. In this respect the $\mathcal{S}$. domuncula protein displays higher similarity to the epidermal growth factor receptor, a non-split RTK. A radial unrooted phylogenetic tree was constructed together with the two protostomian sequences ( $D$. melanogasterand $C$. elegans) and the sponge RTK from $G$. cydonium. Based on this comparison, the $S$. domuncula kinase clusters together with the human plateletderived growth factor receptor (Fig. 2B).

\section{Recombinant receptor tyrosine kinase RTKvs and immuno- histochemistry}

The polyclonal antibodies PoAb-RTKvs were used for an immunohistochemical analysis. Cross sections were perfomed through specimens collected from the area of Rovinj. Oocytes and early embryonic stages could only be identified in specimens collected in the early summer season. They are strongly stained with the PoAb-RTKvs (Fig. 3). Oocyte formation is predominantly seen adjacent to the cortex region of the specimen. The rim of small hollow structures $(<5 \mu \mathrm{m})$ reacted with these antibodies due to an 'edge-effect'; these holes had been created artificially by the dissolution of the spicules and do not reflect native cellular structures. Pre-immune rabbit serum did not show any reaction with tissue structures; likewise no staining was obtained if the tissue slices were only incubated with the secondary antibody (data not shown). The PoAb-RTKvs are the first tool available to specifically stain reproduction bodies in $S$. domuncula and may cross react with these structures in other species of sponge. It is interesting to note that in the same specimen different differentiation states, ranging from oocytes to larvae, can be detected with PoAb-RTKvs. The following stages have been identified: (i) oocytes of a size of $\approx 90 \mu \mathrm{m}$ (Fig. 3A) can be visualized in close vicinity to the canals. The mature eggs contain yolk (vitelline) inclusions. The prominent nucleus (measuring $5 \mu \mathrm{m}$ ) can be seen on other sections (Fig. 3 B,C). The oocytes and also the later stages during larvae formation, are surrounded by a delimiting (= follicle) epithelium, which is not stained in small cavities (Fig. 3). (ii) Later stages of larval development could also be identified in the same specimen such as embryos at the morula stage (Fig. 3D). The size and the appearance of the morula is similar to that described from the demosponge Neocoelia crypta(Vacelet, 1979). Again, this stage is well embedded in a cavity surrounded by a follicle epithelium. (iii) The next stage observed is the developing (Fig. 3E) and mature larva (Fig. 3F). The morphology of the $\mathcal{S}$.

A

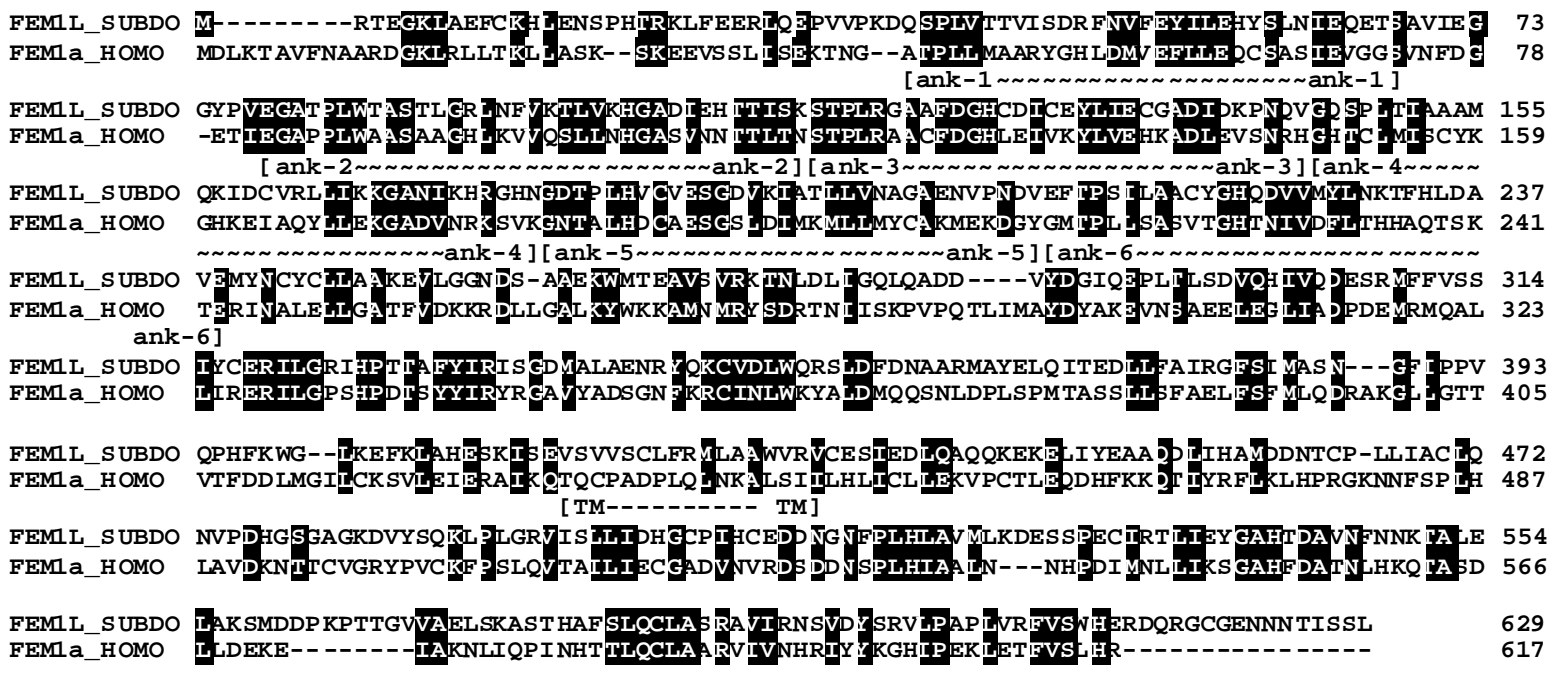

B

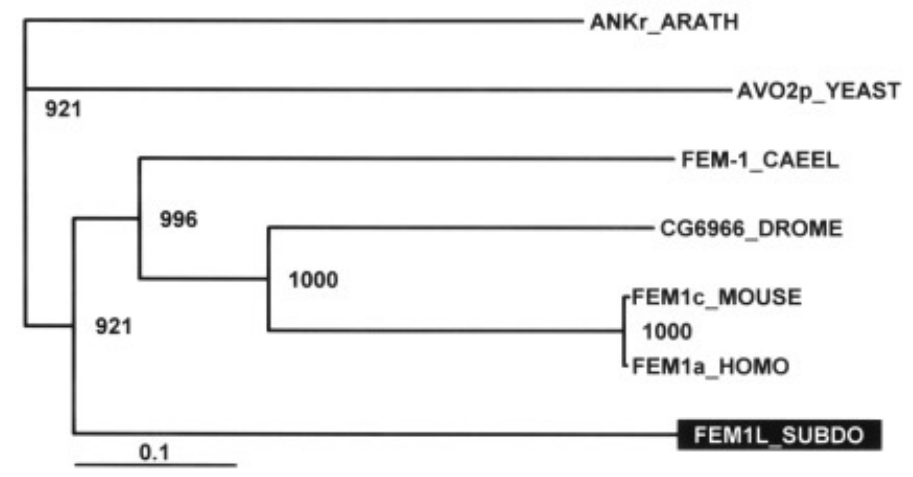

Fig. 5. S. domuncula FEM-like protein. (A) The sponge polypeptide FEM1L_SUBDO is aligned with human protein feminization 1 homolog a (FEM1a_HOMO, accession number AY249188). The borders of the six characteristic ankyrin repeats [ank] are given; the transmembrane region is marked [TM]. (B) Rooted phylogenetic tree constructed from these two FEM proteins together with the related proteins from mouse, the fem-1 homolog C (FEM1C_MOUSE, NP_775599), the hypothetical protein CG6966-PA (CG6966_DROME, NP_650415), the feminization 1 homolog from C. elegans (FEM-1_CAEEL, NP_500824.1; Krakow et al., 2001), as well as the distantly related sequences from the yeastS. cerevisiae Avo2p (AVO2p_YEAST, NP_013784.1) and from the plantA. thaliana, the ankyrinrelated protein (ANKr_ARATH, NP_178442.2). After alignment the tree was built and rooted using the plant sequence as an outgroup. 
domunculalarva is the same as that described for Hymeniacidon caruncula (Diaz, 1973) and can be termed a coeloblastulae. No characteristic spermatocytes could be unequivocally identified. However, since oocytes as well as larval stages have been identified in the same specimen, it may be concluded that the fertilization of the oocytes occurs internally and the larvae are released. Hence, in $\mathcal{S}$. domuncula the development of the embryos is distinguished from that of $S$. massa which has been described to be oviparous (Diaz, 1973 and 1979a).

\section{Seasonality of RTKVs_SUBDO protein expression level}

The protein expression level of the SDRTKVS gene has been quantitatively assessed with PoAb-RTKvs by Western blotting. Animals had been collected throughout the year 2001 in the Adriatic Sea. Extracts were prepared and the same amount of protein was subjected to Western blot analysis using the antibodies PoAb-RTKvs. As expected from the calculated size of the RTK (calculated $M_{r}$ of 89,431 ) a band of approximately $90 \mathrm{kDa}$ was observed after reacting the blot with a labeled secondary antibody (Fig. 4B); the corresponding Coomassie stained gel is also shown (Fig. 4A). Since, as expected, the expression level of a regulatory receptor is low, several nonspecific background bands appeared. Specimens from January/February (lane a: 1/2 in Fig. 4), May/ June (b: 5/6), July/August (c: 7/8) and September (d: 9) were analyzed. It is shown that the band corresponding to $90 \mathrm{kDa}, \mathrm{co}-$ migrating with the sponge RTK, is absent in winter while a strong reaction is seen in late spring/early summer and it subsequently declines in strength towards the autumn (Fig. 4B). A graphical representation of the intensities of the $90 \mathrm{kDa}$ band is given in Fig. 4C.

\section{Putative sponge sex-differentiation gene FEM1 and its de- duced protein}

From the $S$. domunculaEST database the complete sequence of SDFEM1L was obtained. The $2000 \mathrm{nt}$ long insert comprises one open reading frame (ORF) ranging from $\mathrm{nt}_{4 / 6}$ to $\mathrm{nt}_{1891-1893 \text { (stop). }}$.
Northern blot analysis revealed a single band of $\approx 2.1 \mathrm{~kb}$, indicating that the clone is of full length (see below). The translation product of SDFEM1L of 629 aa has a calculated size of Mr 69,936 and was named FEM1L_SUBDO (Fig. 5A). Six characteristic ankyrin repeats can be identified (Isrec-Server, 2003), which are at the same positions within FEM1L_SUBDO as in sequences of other animals (Fig. 5A). One transmembrane region can be found which ranges from $\mathrm{aa}_{415}$ to $\mathrm{aa}_{431}$ (Rao and Argos, 1986; Fig. 5A).

\section{Phylogenetic analysis}

FEM1L SUBDO showed a high similarity with the metazoan feminization proteins in database analysis. The sponge FEM protein has, except for the arrangement of the ankyrin repeats, no high overall similarity to related proteins in other metazoans. The human feminization 1 homolog protein [group c] (accession number AY249188; Ventura-Holman et al., 2003) and the sponge protein show a correlation of $43 \%$ similarity and $25 \%$ identity. The relationship to other metazoan proteins is in the same order of magnitude, including the feminization 1 homolog a from $C$. elegans (Krakow et al., 2001). Only a distant similarity exists with the yeast or plant sequences $(<20 \%$ similarity $/<10 \%$ identity). Hence, the tree rooted with the plant protein shows that the $\mathcal{S}$. domunculaFEM protein forms the basis of metazoan proteins (Fig. 5B). The FEM1 protein family in C. elegans comprises three members, FEM1a, FEM1b and FEM1c (Ventura-Holman et al., 2003). While FEM1a and FEM1b are closely related, FEM1c has been considered to be a more distantly related member (Ventura-Holman et al., 2003). In the tree presented here, the highest sequence similarity of the sponge FEM1 protein exists with the FEM1c protein from human and FEM1a from $C$. elegans. Hence, the sponge FEM1L_SUBDO forms the basis of the metazoan FEM family members.

\section{Sponge gene coding for sperm associated antigen}

The complete cDNA from the $\mathcal{S}$. domunculagene encoding the sperm associated antigen-related protein has been isolated and sequenced. The 902 nt long insert, termed SDSAAr, comprises

A

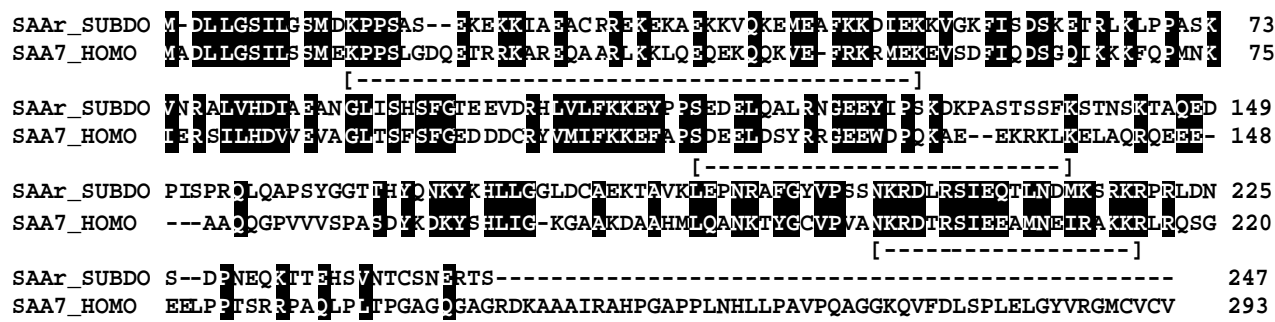

Fig. 6. Sponge sperm associated antigen. (A) The deduced and complete S. domuncula polypeptide

B

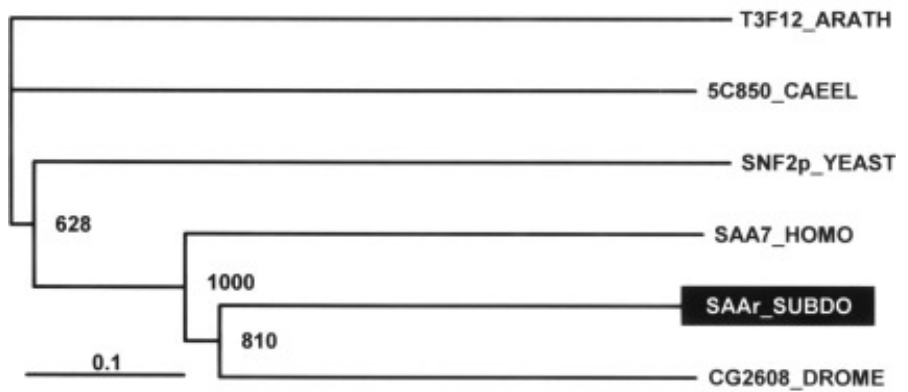

(SAAr_SUBDO) is aligned with the human sperm associated antigen 7 (SAA7_HOMO, NP_004881). The hydrophilic segments are underlined (hatched lines). (B) The sponge and the human sequences were compared with the following sequences to construct a rooted tree: the hypothetical polypeptide CG2608-PA from D. melanogaster (CG2608_DROME, NP_610042); the C. elegans polypeptide (5C850_CAEEL, NP_503655.2) a distantly related putative protein with at least 11 transmembrane domains; the yeast [S. cerevisiae] regulator of phospholipid synthesis Snf2p (SNF2p_YEAST, NP_014933.1); the hypothetical protein T3F12.5 from A. thaliana (T3F12_ARATH, T00944) which was used as outgroup. 
between $\mathrm{nt}_{58 / 60}$ to $\mathrm{nt}_{799 / 801 \text { (stop) }}$ the ORF for the putative sperm associated antigen-related protein, SAAr_SUBDO (Fig. 6A). The 247 aa long polypeptide has a calculated $\mathrm{Mr}$ of 27,791. The first protein of this family was found from fox and was named FSA-1 (Beaton et al., 1994). Later the human homologue was identified (accession number NP_004881) as sperm associated antigen 7. As reported in the first study (Beaton et al., 1994) FSA-1 comprises no specific domain found in other proteins, but large stretches of hydrophilic regions. In the $\mathcal{S}$. domunculaSAAr_SUBDO these hydrophilic segments are also present. No eukaryotic signal peptide could be predicted PC/GENE (1995). In order to check the size of the transcript of $S D S A A$, Northern blot analysis was performed that revealed a size of $0.9 \mathrm{~kb}$ (Fig. 7).

\section{Phylogenetic analysis \\ The phylogenetic analysis is interesting, since the sponge sequence SAAr_SUBDO shares a high sequence relationship with the human sperm associated antigen 7 sequence and the insect (D. melanogaster) polypeptide CG2608-PA (NP_610042); the similarity score to them is high $(>50 \%$ similarity $/>40 \%$ iden- tity). Because no similar protein exists in $C$. elegans, yeast ( $S$. cerevisiae) and plant ( $A$. thaliana) databases, the relation to the latter three organisms cannot be resolved in the rooted phyloge- netic tree. However, the sponge, human and insect sequences cluster together (Fig. 6B). The lack of a related sperm associated antigen sequence in $C$. elegans confirms earlier suggestions that the nematode with its reduced genome underwent an accelerated evolution (Gamulin et al., 2000).}

\section{Expression studies of the genes SDRTKvs, FEM and SAAr}

The results summarized in the previous sections suggest that the expression of the marker genes indicative for sex-differentiation, is season-dependent. One factor for this modulation, as reported for $\mathcal{S}$. massa, is a change of temperature (Diaz, 1973; Diaz, 1979a and 1979b). A close correlation was established between a temperature shift of about $7^{\circ} \mathrm{C}$ during May and the production of oocytes. Since $\mathcal{S}$. domuncula lives in a depth of around $20 \mathrm{~m}$, in a biotope which shows only moderate changes of temperature of approx. $5^{\circ} \mathrm{C}$ from spring/summer to winter, specimens were treated in the aquarium at the elevated temperature (from $18^{\circ} \mathrm{C}$ to $22^{\circ} \mathrm{C}$ ) for up to five days. Northern blot experiments were performed as described under "Materials and Methods" to determine any change in the level of expression of the three genes after temperature treatment. The experiments revealed that almost no signal could be detected in RNA prepared from non-treated animals using the probe for SDRTKVS, for FEM1 (SDFEM1), or for the sperm associated antigen (SDSAA) (Fig. 7). However, RNA analysis of specimens treated at an elevated temperature, showed a more than 3-fold increase in the expression of these 3 genes (Fig. 7). The housekeeping gene $\beta$-tubulin cDNA ( $S D T U B$ ) was used as a control; its expression level did not change.

\section{Identification of cells, expressing SDFEM1L or SDSAAr}

Cryosections were prepared and hybridization was performed with labeled probes for FEM1 (SDFEM1L) and for sperm associated antigen ( $S D S A A$ ) Fig. 8. Sections from tissue which had been maintained at $18^{\circ} \mathrm{C}$ did not show any signal using antisense SDFEM1L (Fig. 8A a) or SDSAAr (Fig. 8B a) ssDNA probes.
However, if the animals had been kept at $22^{\circ} \mathrm{C}$, expression of both genes was observed in cells surrounding the aquiferous canal system, for SDFEM1L (Fig. 8A b,c) or for SDSAAr (Fig. 8B b,c) after 3 days. A further increase in the intensity of the hybridization signal occurred if the incubation at $22^{\circ} \mathrm{C}$ was carried out for 5 days; for SDFEM1L (Fig. 8A d-f) or for SDSAAr(Fig. 8B d-f). It is worthy of note that the cells which react with these probes cluster together and some of these cell bodies start to grow out from the tissue; e.g. for SDFEM1L (Fig. 8A e,f) or for SDSAAr (Fig. 8B d$f)$. No reaction is seen if the cells are treated with both sense probes (not shown).

\section{Discussion}

The central focus of this report is on the plasticity of sponge cells and the differentiation of germ cells in particular. Until 1998 (Ferrari et al., 1998) it was accepted that in mammalian systems only embryonic stem cells are pluripotent (Blau et al., 2001). This view, however, has changed since it has been experimentally proven that adult stem cells also have the propensity to differentiate into several cell lineages (reviewed in: Blau et al., 2001; Engelhardt et al., 2003). The consequence of this new stem cell concept is that these adult cells comprise a high plasticity and are able to differentiate into multiple cell types, depending on their environment, meaning that the "differentiation point of no return" might not exist for some cell types (Jiang et al., 2002).

In the light of these new studies on mammalian systems, it is interesting to revisit the question of sponge cell differentiation and plasticity. In 1979 (Diaz, 1979b) it was suggested that sponge cells have the potency to differentiate into (almost) any cell type via the archaeocyte stage. This view was opposed by the assumption that - with a few exceptions (Connes et al., 1972) - the differentiation from archaeocytes induces irreversible changes which eliminate their pluripotent propensity (Simpson, 1984). With respect to germ cells in sponges, the majority of studies on spermatogenesis report the development of spermatids from spermatocysts and spermatogonia, originating directly from func-

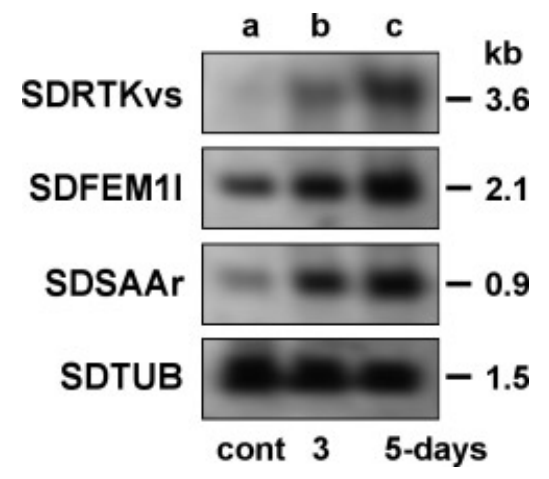

Fig. 7. Steady-state expression of the gene for the S. domunculaRTK/ FGFR (SDRTKvs), FEM1 (SDFEM1I) and the sperm associated antigen (SDSAAr) in response to a temperature shift from $18^{\circ} \mathrm{C}$ to $22^{\circ} \mathrm{C}$. The animals were exposed as described under "Materials and Methods". Subsequently, RNA was isolated and equal amounts were size-separated, transferred and probed with the labeled SDRTKvs, SDFEM1I or SDSAAr $c D N A$ probes. As an internal standard the RNA samples were probed with the $S$. domuncula $\beta$-tubulin cDNA (SDTUB). Lanes: (a) control material, (b) after 3 days and (c) after 5 days at an elevated temperature. 

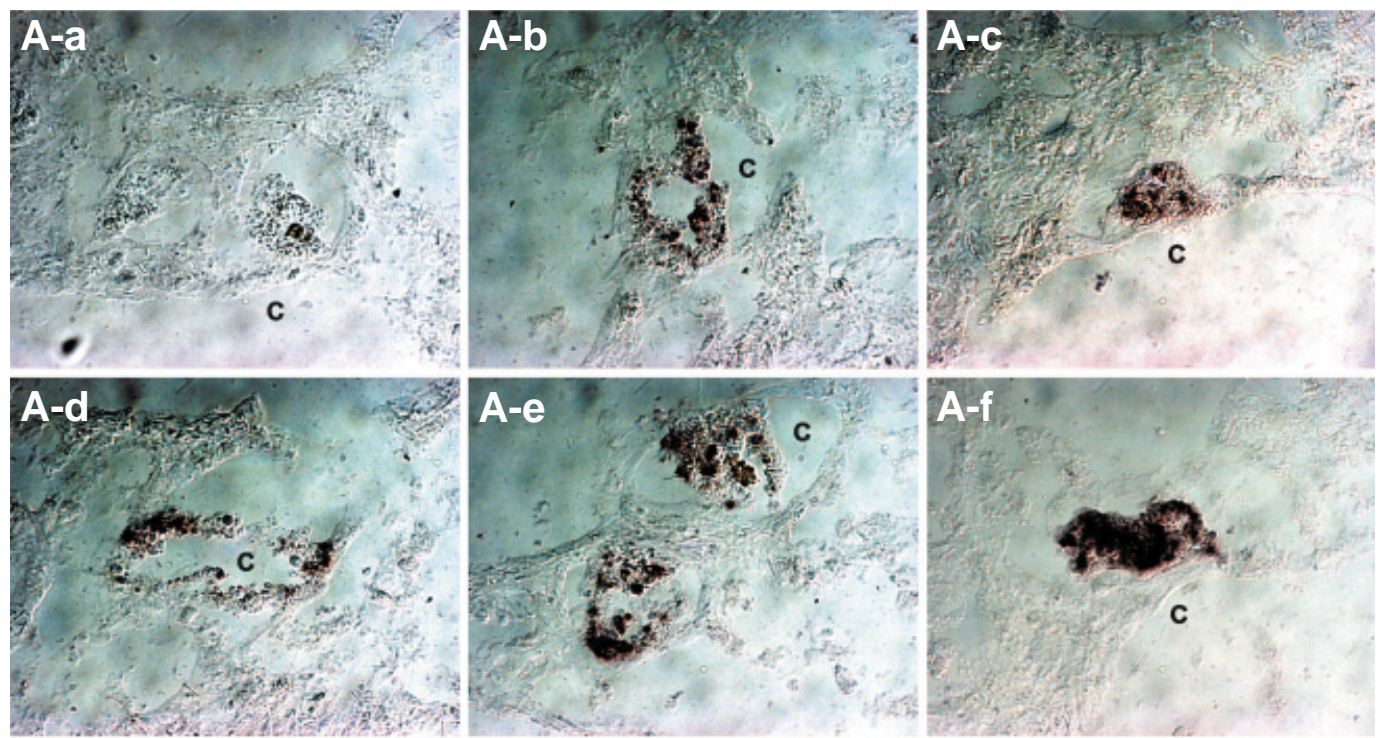

Fig. 8. Detection of cells express-
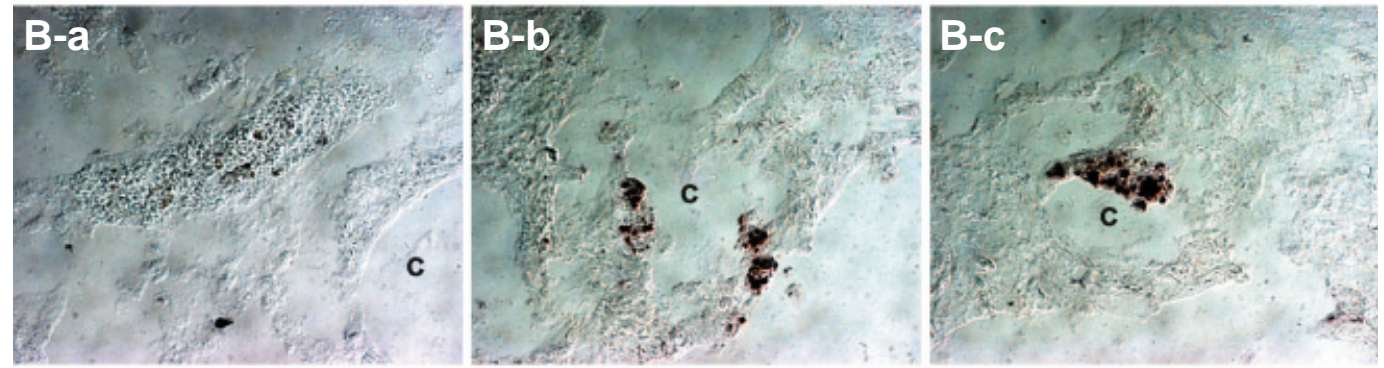

antigen. (A) In situ hybridization performed withSDFEM1l as a probe. (B) In situ analysis with the SDSAAr probe. Cryosections were taken from specimens which remained at the constant temperature of $18^{\circ} \mathrm{C}$ [micrographs (a), control], or from samples of animals which were kept at $22^{\circ} \mathrm{C}$ for 3 days $(b, c)$ or 5 days $(d$ - f). Hybridised cells are stained by a brown/black deposit and canals (c) of the aquiferous system within the mesohyl are shown. The in situ hybridization experiments were performed with the two probes, at the indicated time points, with the same animals. Magnification, $x 30$.
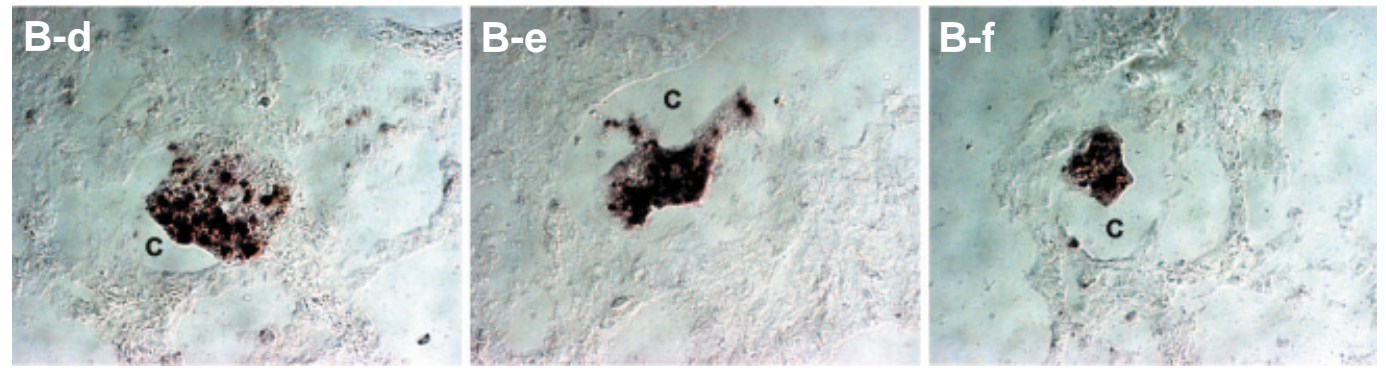

tional choanocyte chambers (Paulus, 1989; Barthel and Detmer, 1990). The origin of oogonia is less clear; they were reported to derive from choanocytes in Suberites massa (Diaz, 1979b), but most authors recognize the precursors of eggs among the mesohyl cells as archaeocytes (Simpson, 1984). Hence, the identification and description of putative stem cells which generate primordial germ cells in sponges has not been possible. However, compelling morphological evidence for the origin of gametes from fully differentiated somatic cells, such as choanocytes, argues against a clear separation of the germinal and somatic cell lineages (Koziol et al., 1998). Gene expression studies, using the sponge in vitro cell system, the primmorphs, allowed a closer insight into the differentiation pathways of the omni/pluripotent archaeocytes in sponges (Müller et al., 2003a and 2003b). It could be established that specific genes are upregulated if archaeocytes are triggered to a differentiation process by specific signals, e.g. silicate. Marker genes have been established, like noggin or silicatein, which strongly suggest that the omni/pluripotent stem cells are located in the epithelial layer of the aquiferous canal

system in sponges and not in the internal tissue, the mesohyl (Schröder et al., 2004), as suggested earlier (Simpson, 1984). This assumption is corroborated by the experiments presented here. The morphological studies performed with $\mathcal{S}$. domuncula showed that the oocytes and larvae are formed in the vicinity of the canal system, as expected since they have to be released via this route. The antibodies directed against the newly described RTK, which were developed during this study, showed that the staining of the oocytes and larvae is restricted to these reproductive bodies. Monitoring the expression of two genes which are possibly involved in sexual-differentiation, the FEM-like gene and the gene encoding the sperm associated antigen, has revealed that they are exclusively induced in cells in the direct vicinity of the canals. Hence, it can be concluded that the differentiation process to the germ cell cysts starts from the epithelium of the endopinacoderm. Future studies must show if the encapsulation of oocytes and larvae into follicle chambers is driven by cells of the canals. Studies in this line are in progress, but they have been hampered by the fact that it was, until now, difficult to synchronize 
sexual reproduction in sponges. Solid work has been performed which revealed that a temperature shift was likely to be the major factor for the induction of gametogenesis (Diaz, 1973; reviewed in: Simpson, 1984). These results led to the design of the experiments in the present study. After raising the water temperature in the aquaria, the $\mathcal{S}$. domuncula specimens started to express the FEM-like gene and also the gene encoding the sperm associated antigen, supporting the possibility of their role in gamete formation. However, other factors, e.g. age and size of the animals, or physical factors, e.g. change in salinity, might also contribute to gametogenesis, even though no conclusive data have been yet presented (Diaz, 1979a and 1979b; and reviewed in: Simpson, 1984).

One major autapomorphic character of Metazoa, perhaps including the choanoflagellates (King and Carroll, 2001), are the receptor tyrosine kinases, which are thought to have first evolved in Porifera, probably from the Ser/Thr kinases (Kruse et al., 1997). The RTK described in the present study is of importance for two reasons. First, the intracellular characteristic and indicative RT domain comprises high sequence similarity to the FGFR family. No member of this class of kinases has been described from Porifera before (Suga et al., 2001). FGFR are known to be involved in embryonic development (Feldman et al., 1995) as well as in normal and abnormal tissue development (Wilkie et al., 1995). Furthermore, the extracellular, ligand-binding segment of this sponge RTK shares no remarkable sequence similarity to any protein stored in the databases. Our hypothesis that this RTK might be involved in embryogenesis in $\mathcal{S}$. domuncula was supported by the antibody studies. Antibodies were raised against the extracellular part of the receptor and immunocytochemistry demonstrated unequivocally that they recognize oocytes and larvae. The suitability of these antibodies can also be deduced from the fact that they recognize not only germ cells, but also larval stages. This specific immunoreactivity implies that the respective embryonal cells contain a distinct set of cell surface markers/antigens whose diversity must be explored further in the future. It is also of interest that the level of gene expression is upregulated after administering a temperature shift to the specimens. These two pieces of evidence suggest that this RTK, RTKvs_SUBDO, plays a controlling function in the development of larvae. Moreover, the data indicate that the FGFR existed prior to the radiation of the triploblasts; this was not clear before (Coulier et al., 1995).

No model system exists for sponges to identify genes expressed in gametogenesis and/or larval developmental, e.g. by differential display of mRNA. Therefore we approached this task by selecting ESTs from our database (http:// spongebase.genoserv.de/) on the basis of sequence/domain similarity to molecules in higher metazoan phyla. Among the most promising sequences are members of the FEM1 family which code for molecules which suppress the development to the female phenotype in the nematode $C$. elegans (Hodgkin, 1986). In mammals the homologues comprise a conserved role in developmental functions (Ventura-Holman et al., 2003). The $\mathcal{S}$. domuncula protein is, like the related molecules from higher phyla, also composed of several ankyrin repeats, positioned in the same regions within the deduced protein. In C. elegansFEM1 regulates the function of the transcription factor tra- 1 which is crucial for female development. Since FEM1, which is involved in protein:protein interaction (Spence et al., 1990), is expressed in
C. elegans in cells of both sexes (Gaudet et al., 1996), its activity must be post-translationally regulated, perhaps by FEM2 which is a Ser/Thr protein phosphatase (Chin-Sang et al., 1996). Studies to further elucidate this pathway in $\mathcal{S}$. domuncula are in progress. At present we have no conclusive, molecular information if $S$. domuncula specimens exist in two sexes and/or as self-fertilizing hermaphrodites, like C. elegans (Hodgkin, 1986). However, the fact that several differentiation stages of larval development can be observed in the same tissue sections, provides some evidence that $S$. domunculamight be a hermaphrodite species. This type of sex determination would also be of advantage for this species because it only rarely lives in dense populations. In addition, this species lives in an environment with high water current were successful fertilization would be very unlikely if gonochorism prevailed. The observed increase of the expression level of SDFEM1L and the location of the expression in situ, is in accordance with our hypothesis that FEM1 functions in $\mathcal{S}$. domuncula during sexual differentiation.

A protein which is known from mammals to stain a $36 \mathrm{kDa}$ sperm antigen (Beaton et al., 1994), was deduced from $\mathcal{S}$. domuncula cDNA and termed 'sperm associated antigen'. In mammals, the monoclonal antibody is specific for spermatids and the occurrence of the gene has been demonstrated for a series of species, suggesting a degree of conservation. In $\mathcal{S}$. domuncula the transcripts have been identified and are especially highly expressed during the summer season. Again, the expression of $S D S A A r$ is highly upregulated in response to temperature shift of $4^{\circ} \mathrm{C}$ after 3 to 5 days. Expression of $S D S A A r a r o u n d$ the canals is the same as that observed for SDFEM1L and it can be stated that both genes ( $S D S A A$ rand $S D F E M 1 L$ ) are expressed in primordial areas which give rise to germ cells. To date, insufficient caryological analysis of sex determination in sponges has been performed (Sarà, 1992) and molecular biological experiments were lacking until the present report. Therefore, conclusive data on cell lineage from totipotent archaeocytes to germ cells, was not available. It was proposed that germ cells may originate from archaeocytes, one of only a few cell types that exist in sponges (Borojevic, 1970; Koziol et al., 1998). However, it was also proposed, especially for the male lineage, that the germ cells originate from choanocytes (Sarà, 1992), suggesting that these cells are the source for both female and male germ cells. The major advance presented in this study is the development of molecular tools which will enable the study of the origin of germ cells in sponges and allow the tracing of their fate during larval development. This was the first, but most difficult step, towards defining sexual differentiation in Porifera. With over 15,000 ESTs from $\mathcal{S}$. domuncula available, the next step will be expression analysis using DNA microarrays.

\section{Materials and Methods}

\section{Chemicals, materials and enzymes}

The sources of most chemicals and enzymes used were given earlier (Kruse et al., 1997; Wimmer et al., 1999; Krasko et al., 2000). Silane-prep slides were obtained from Sigma-Aldrich (Taufkirchen, Germany); nitro blue tetrazolium (NBT) and 5-bromo-4-chloro-3-indolyl phosphate (X-phosphate) from Roth (Karlsruhe; Germany); blocking reagent for nucleic acid hybridization and detection, anti-digoxigenin Fab fragments from Roche Diagnostics $\mathrm{GmbH}$ (Mannheim; Germany); Tissue-Tek from Sakura (Zoeterwoude; The Netherlands); ammonium fluoride $\left(\mathrm{NH}_{4} \mathrm{~F}\right)$, fluoric acid $48 \%(\mathrm{HF})$ and paraformaldehyde (PFA) from Aldrich-Sigma (Taufkirchen; Germany). 


\section{Sponges}

Live specimens of $\mathcal{S}$. domuncula (Porifera, Demospongiae, Hadromerida) were collected in the Adriatic Sea near Rovinj (Croatia). These sponge specimens live commensally with a hermit crab Pagurites oculatus [Decapoda: Paguridea], which resides predominantly in shells of the mollusk Trunculariopsis trunculus [Gastropoda: Muricidae]. The sponges were immediately analyzed after collection or kept in Mainz (Germany) for over 12 months prior to their use. The sponge material (previously termed Suberites ficus) obtained for histological and systematic analysis was collected in Loch Fyne, Argyll, Scotland and immediately frozen to $-80^{\circ} \mathrm{C}$ or fixed for histology. These particular specimens encrusted the shell of the bivalve Chlamys opercularis [Bivalvia: Amusiidae]. To confirm species identity, sequence analyses of rRNA (18S and 28S) were performed at the genomic level. The rRNA of the small as well as of the large subunit, together with the LSU and SSU regions, was compared between $S$. domuncula (phenotype Adriatic Sea) and $S$. ficus (Scotland) specimens. The rRNA sequence from $S$. ficuswas taken from the database (Medina et al., 2001). From S. domunculaa 1737 nt segment from the SSU rRNA sequence was cloned and sequenced, according to standard procedures (Ausubel et al., 1995) and compared with the corresponding stretch from $S$. ficus (accession number AF100947; $\mathrm{nt}_{1}$ to $\left.\mathrm{nt}_{1738}\right)$. The result revealed a $100 \%$ identity between the two sequences. The same approach was performed with the LSU rRNA sequence. Again, a 3106 nt long segment from the $\mathcal{S}$. domuncula LSU rRNA was sequenced and compared with the corresponding sequence from S. ficus (Medina et al., 2001; AY026381; $\mathrm{nt}_{1}$ to $\mathrm{nt}_{3055}$ ). Among the 12 differences found between the $\mathcal{S}$. domuncula and $\mathcal{S}$. ficus sequence, only two changes appeared to be real; the others are considered as ambiguities, e.g. if compared with the other corresponding sponge sequences such as the Mycale fibrexilis 28S large subunit rRNA gene (AY026376). Based on this finding we adopt, in accordance with Burton (1953), the view that $\mathcal{S}$. domuncula and $\mathcal{S}$. ficus are the same species (Suberites domuncula sensuBurton, 1953) having different morphotypes, likely due to the different substrate they grow on and both have been used in the current study. The sponges in the aquarium were kept at $18^{\circ} \mathrm{C}$. For the studies to determine the temperature-dependent expression level of the two genes FEM (SDFEM1L) and sperm associated antigen (SDSAAr), specimens were kept at $22^{\circ} \mathrm{C}$ for up to 5 days, prior to Northern blot analysis.

\section{Histological analysis}

Fresh sponge tissue from the Adriatic Sea was fixed in $2 \%$ paraformaldehyde (Romeis, 1989); after dehydration the samples were embedded in Technovit 8100 (Beckstead, 1985), according to the instructions of the manufacturer as outlined in Pancer et al. (1996). Sections of $8 \mu \mathrm{m}$ thickness were prepared. The sections were stained with the trichrome stain ASTRIN (Kovács etal., 1982) and subsequently inspected. Samples from the Atlantic were fixed and stored in Bouin's for at least two weeks to aid softening of the spicules. They were then embedded in wax, sectioned and stained using haematoxylin and eosin by standard methods. Tissue samples from sponge specimens, either from the Adriatic Sea (Rovinj) or from the Atlantic (Scotland) were collected throughout the annual season or used after maintenance in the aquarium.

\section{In situ hybridization}

To remove the silica spicules from the tissue of $\mathcal{S}$. domuncula small pieces of sponge tissue were incubated with $\mathrm{HF} / \mathrm{NH}_{4} \mathrm{~F}$. After incubation and washing the sponge pieces were embedded in Tissue-Tek and kept in isopentane at $-80^{\circ} \mathrm{C}$ before cutting.

In situ hybridization was performed with digoxigenin-labeled (DIG) ssDNA probes. Labeling was carried out with the "PCR DIG Probe synthesis Kit" (Roche). DNA oligonucleotide probes were constructed, based on the $S$. domuncula cDNAs. The SDFEM1L probe was $523 \mathrm{bp}$ long ( $\mathrm{nt}_{172}$ to $\left.\mathrm{nt}_{694}\right)$. The SDSAArprobe covered the segment from $\mathrm{nt}_{169}$ to $\mathrm{nt}_{571}$ (403 bp). The hybridization method was described previously (Polak and McGee, 1998) with essential modifications (Perovic et al.,
2003). 8- $\mu \mathrm{m}$ thick cryosections (on "Silane-prep slides") were fixed with paraformaldehyde and washed with PBS at room temperature. The sections were incubated with $1 \mu \mathrm{g} / \mathrm{ml}$ of Proteinase $\mathrm{K}$ for $30 \mathrm{~min}$ at room temperature. After treatment, the sections were fixed again with paraformaldehyde. To remove color from the cells, the sections were incubated with increasing concentrations of ethanol and finally with isopropanol. After rehydration the sections were hybridized with DIG-labeled antisense and sense ssDNA probes. Sense probes were used in parallel as negative controls in the experiments. After blocking, the sections were incubated for $1 \mathrm{~h}$ at $37^{\circ} \mathrm{C}$ with an anti-DIG antibody conjugated with alkaline phosphatase. After two washes the dye reagent NBT/X-Phosphate in a Tris-buffer (100 mM Tris/ $\mathrm{HCl}, \mathrm{pH} 9.5 ; 100 \mathrm{mM} \mathrm{NaCl}$ and $50 \mathrm{mM} \mathrm{MgCl}_{2}$ ) was used for visualization of the signals.

\section{S. domuncula receptor tyrosine kinase (SDRTKvs)}

In a screening program for tyrosine kinases from $\mathcal{S}$. domuncula, degenerative primers were used to amplify parts of cDNAs encoding TK subdomains VIb-IX (Cetkovic et al., 2004). Polymerase chain reaction (PCR) was performed on the total $\mathcal{S}$. domuncula cDNA library prepared in a Lambda ZAP Express vector (Kruse et al., 1997) and amplified fragments were cloned and sequenced. Numerous TK subdomains VIbIX have been identified. In the next step, the mixture of digoxygenin-11dUTP labeled cDNA fragments encoding TK subdomains VIb-IX was used as a hybridization probe to screen the $\mathcal{S}$. domuncula cDNA library. Several cDNAs encoding TKs were identified and sequenced using the automatic DNA sequenator AlfExpress (Cetkovic et al., 2004). We describe here a 3516 nt long CDNA, termed SDRTKVS which codes for RTKvs_SUBDO.

\section{Sponge sex-differentiation genes FEM1 and sperm associated anti-} gen

From the $\mathcal{S}$. domunculaEST data base (http://spongebase.genoserv.de) partial sequences for a FEM1 and a sperm associated antigenwere selected. The sequences, termed SDFEM1L, encoding a putative FEM1L protein (FEM1L_SUBDO) and SDSAAr, from which the sponge sperm associated antigen-related protein has been deduced (SAAr_SUBDO), were completed by 5'- and 3'-RACE. The complete cDNAs, SDFEM1L with a size of $2000 \mathrm{nt}$ in the insert and $S D S A A r$ with a length of $902 \mathrm{nt}$, were obtained.

\section{Sequence analysis}

The sequences were analyzed using computer programs Blast (2003) and FASTA (2003). Multiple alignments were performed with CLUSTAL W Ver. 1.6 (Thompson et al., 1994). Phylogenetic trees were constructed on the basis of aa sequence alignments by neighbor-joining, as implemented in the "Neighbor" program from the PHYLIP package (Felsenstein, 1993). The distance matrices were calculated using the Dayhoff PAM matrix model as described (Dayhoff et al., 1978). The degree of support for internal branches was further assessed by bootstrapping (Felsenstein, 1993). The graphic presentations were prepared with GeneDoc (Nicholas and Nicholas, 1997).

\section{RecombinantS. domuncula receptortyrosine kinase RTKvs_SUBDO and raising of antibodies}

The extracellular part of the RTKvs SUBDO from $\mathcal{S}$. domuncula was expressed using the corresponding segment of the SDRTKVS. The cDNA section was isolated by PCR using the forward primer f1 (5'-GGA TCC ATG CTA ACA AAT AGA GCT CAA AAG-3' [the Bam HI restriction site is in italics and underlined]; $\mathrm{nt}_{658}$ to $\left.\mathrm{nt}_{682}\right)$ and the reverse primer $\mathrm{r}^{1}$ (5'CTC GAGGGT AAT ACA TCC ATT ATC ACC AAG-3' [Xhol]; $\mathrm{nt}_{1740}$ to $\left.\mathrm{nt}_{1764}\right)$. The length of the PCR product of $1107 \mathrm{bp}$ was used for expression in $E$. coli. The cDNA was cloned into the bacterial glutathione-S-transferase/oligohistidine/S expression vector pET41a (Novagen, Madison $\mathrm{WI}$; USA) via the corresponding restriction sites. After transformation with this plasmid, expression of fusion protein was performed in $E$. colistrain BL21 for $6 \mathrm{~h}$ at $37^{\circ} \mathrm{C}$ with $1 \mathrm{mM}$ isopropyl 1 -thio- $\beta$-D-galactopyranoside (IPTG) (Ausubel et al., 1995). The fusion protein was extracted and 
purified first using the His "tag purification kit (Novagen, Madison WI; USA) and subsequently with the glutathione-S-transferase "tag purification kit (Pharmacia, Freiburg; Germany) as recommended by the manufacturer. Finally, the fusion protein was cleaved with enterokinase (5 units; Novagen) as recommended. The recombinant RTK, r-RTKvs, was obtained tag-free through purification in a batch procedure using the glutathione-S-transferase "tag purification kit; the recombinant protein remained in the supernatant. The purity of the material was checked by $10 \%$ polyacrylamide gels containing $0.1 \%$ NaDodSO 4 according to Laemmli (1970). The protein was dialyzed against $25 \mathrm{mM}$ Tris- $\mathrm{HCl}$ buffer ( $\mathrm{pH} 7.2)$.

Polyclonal antibodies (PoAb) were raised against the recombinant sponge r-RTKvs in female rabbits (White New Zealand) as described (Schütze et al., 2001). After three boosts the serum was collected and screened in a conventional ELISA assay as well as by Western blotting; the PoAb were termed PoAb-RTKvs. In control experiments $100 \mu \mathrm{l}$ of the PoAb-RTKvs were adsorbed to $20 \mu \mathrm{g}$ of $\mathrm{r}$-RTKvs (30 min; $4^{\circ} \mathrm{O}$ ) prior to use; this preparation did not recognize any protein in the Western blot analysis (data not shown).

\section{Immunohistochemistry}

After fixation, tissue was treated with $\mathrm{HF} / \mathrm{NH}_{4} \mathrm{~F}$ to remove the spicules (Perovic etal., 2003). $8 \mu \mathrm{m}$ thick sections were prepared and permeabilized by incubation with methanol. After blocking with $0.3 \%$ bovine serum albumin for $30 \mathrm{~min}$, sections were incubated with PoAb-RTKvs (1:250 dilution) overnight at $4^{\circ} \mathrm{C}$. Then, after washing, alkaline phosphatase conjugated goat anti-rabbit immunoglobulin (Dako, Carpinteria; Germany) was used as a secondary antibody (1:40). The sections were incubated with the substrate NBT/ $x$-Phosphate and inspected microscopically.

\section{Western blotting}

For the identification of RTKvs_SUBDO in sponge tissue, extracts were prepared as described (Böhm et al., 2000). Tissue samples were homogenized in lysis-buffer (1x TBS [Tris-buffered saline], $\mathrm{pH} 7.5,1 \mathrm{mM}$ EDTA, $1 \%$ Nonidet-P40, $10 \mathrm{mM} \mathrm{NaF}$, protease inhibitor cocktail (Roche, Mannheim; Germany) [ 1 tablet/10 ml]), centrifuged and the supernatants were subjected to Western blot analysis. The extracts were subjected to $10 \%$ polyacrylamide gels $/ 0.1 \%$ NaDodSO4 (PAGE) as described (Laemmli, 1970). The membranes were incubated with rabbit PoAbRTKvs (1:500 dilution); the immune complexes were visualized by incubation with anti-rabbit IgG (alkaline phosphatase conjugated), followed by staining with 4-chloro-1-naphthol. To quantitate a given signal on the blots, scanning with the GS-525 Molecular Imager (Bio-Rad) was performed. The relative values, with respect to the highest signal (set to 1.0) seen, are given.

\section{RNA preparation and Northern blot analysis}

RNA was extracted from liquid-nitrogen pulverized tissue with TRIzol Reagent (GibcoBRL, Grand Island, N.Y.) as described (Grebenjuk et al., 2002). Then $5 \mu \mathrm{g}$ of total RNA was electrophoresed and blotted onto Hybond-N+ nylon membrane (Amersham; Little Chalfont, Buckinghamshire; UK). Hybridization was performed with a $550 \mathrm{nt}$ large part of then SDRTKVSCDNA, a $600 \mathrm{nt}$ long SDFEM1L probe and a $350 \mathrm{nt}$ segment of the SDSAAr cDNA. Regions spanning the open reading frames (ORF) were selected. The house-keeping gene $\beta$-tubulin, SDTUB (accession number AJ550806), of $\mathcal{S}$. domunculawas used as an internal standard. The probes were labeled with the PCR-DIG-Probe-Synthesis Kit (Roche, Mannheim; Germany). After washing DIG-labeled nucleic acid was detected with anti-DIG Fab fragments and visualized by chemiluminescence technique using CDP (Roche).

\section{Acknowledgements}

We thank Dr. J. Vacelet (Station Marine d'Endoume, Marseille) for advice in the histological analysis. This work was supported by grants from the Deutsche Forschungsgemeinschaft [Mü/14-3], the Bundesministerium für Bildung und Forschung, Germany [project: Center of Excellence BIOTECmarinj and the International Human Frontier Science Program (RG-333/96-M). HC and VG were supported by Croatian project 0098072 and CM was supported by EU project MAS-3-CT98-0179.

\section{References}

ADELL, T., GAMULIN, V., PEROVIC-OTTSTADT, S., WIENS, M., KORZHEV, M., MÜLLER, I.M. and MÜLLER, W.E.G. (2004). Evolution of metazoan cell junction proteins: The scaffold protein MAGI and the transmembrane receptor tetraspanin in the demosponge Suberites domuncula. J. Mol. Evol; in press (DOI: 10.1007/ s00239-004-2602-2).

AUSUBEL, F.M., BRENT, R., KINGSTON, R.E., MOORE, D.D., SMITH, J.A., SEIDMANN, J.G. and STRUHL, K. (1995). Current Protocols in Molecular Biology. (New York: John Wiley and Sons).

BARTHEL, D. and DETMER, A. (1990). The spermatogenesis of Halichondria panicea (Porifera, Demospongia). Zoomorphology 110: 9-15.

BEATON, S., CLEARY, A., TEN HAVE, J. and BRADLEY, M.P. (1994). Cloning and characterization of a fox sperm protein FSA-1. Reprod. Fertil. Dev. 6: 761-770.

BECKSTEAD, J. H. (1985). Optimal antigen localization in human tissues using aldehydefixed plastic-embedded sections. J. Histochem. Cytochem. 9: 954-958.

BLAST (2003). http://www.ncbi.nlm.nih.gov/blast/blast.cgi; ; INTERNET.

BLAU, H.M., BRAZELTON, T.R. and WEIMANN, J.M. (2001). The evolving concept of a stem cell: entity or function? Cel/105: 829-841.

BLUMBACH, B., PANCER, Z., DIEHL-SEIFERT, B., STEFFEN, R., MÜNKNER, J., MÜLLER, I. and MÜLLER, W.E.G. (1998). The putative sponge aggregation receptor: isolation and characterization of a molecule composed of scavenger receptor cysteine-rich domains and short consensus repeats. J. Cell. Sci. 111: 2635-2644.

BÖHM, M., MÜLLER, I.M., MÜLLER, W.E.G. and GAMULIN, V. (2000). The mitogenactivated protein kinase p38 pathway is conserved in metazoans: cloning and activation of p38 of the SAPK2 subfamily from the sponge Suberites domuncula. Biol. Cel/29: 95-104.

BOROJEVIC, R. (1966). Étude expérimentale de la différentiation des cellules de I' éponge au cours de son développement. Dev. Biol. 14: 130-153.

BOURY-ESNAULT, N. and RÜTZLER, K. (1997). Thesaurus of Sponge Morphology. (Washington: Smithsonian Institution Press).

BURTON, M. (1953) Suberites domuncula (Olivi): its synonymy, distribution and ecology. Bull. Brit. Mus. (Nat. Hist.) 1: 353-378.

CARTER, H.J. (1883). On the presence of starch granules in the ovum of the marine sponges and on the ovigerous layer of Suberites domuncula, Nardo. Ann. Mag. Natural. Hist. 12: 30-36.

CETKOVIC, H., MÜLLER, W.E.G. and GAMULIN, V. (2004). Bruton's tyrosine kinaselike protein, BtkSD, is present in the marine sponge Suberites domuncula. Genomics 83: $743-745$

CHIN-SANG, I.D. and SPENCE, A.M. (1996). Caenorhabditis eleganssex-determining protein FEM-2 is a protein phosphatase that promotes male development and interacts directly with FEM-3. Genes Dev. 10: 2314-2325.

CONNES, R., DIAZ, J.P. and PARIS, J. (1972). Variations saisonnières des populations cellulaires de l'éponge Suberites massa Nardo. I. Étude histologique et cytologique. Bull. Mus. Nat. Natur. (Paris), 3rd Ser. 84: 1013-1038.

CONNES, R., PARIS, J. and ARTIGES, J.M. (1974). L' origine des cellules blastogenetiques chez Suberites domuncula Nordo. L' équilibre choanocytesarchaeocytes chez les spongiaires. Ann. Sci. Natur. Zool. (Paris) 16: 111-118.

COULIER, F., PONTAROTTI, P., ROUBIN, R., HARTUNG, H., GOLDFARB, M. and BIRNBAUM, D. (1997). Of worm and men: an evolutionary perspectives on the fibroblast growth factor (FGF) and FGF receptor families. J. Mol. Evol. 44: 43-56.

DAYHOFF, M.O., SCHWARTZ, R.M. and ORCUTT, B.C. (1978). A model of evolutionary change in protein. In Atlas of Protein Sequence and Structure. M.O. Dayhoff, ed., pp. 345-352. (Washington, DC., Nat. Biomed. Res. Foundation).

DIAZ, J.P. (1973). Cycle sexuel de deux demosponges de l'etang de Thau: Suberites massa Nardo et Hymeniacidon caruncula Bowerbank. Bull. Soc. Zool. France 98: 145-156.

DIAZ, J.P. (1979a). La degenerescence ovocytaire chez la demosponge Suberites massa. In Biologie des Spongiaires, C. Lévi and N. Boury-Esnault, eds. Colloq Internat CNRS (Paris)291: 79-86. 
DIAZ, J.P. (1979b). Variation, différentiations et fonctions des catégories cellulaires de la demosponge d'eaux saumatres, Suberites massa, Nardo, au cours du cycle biologique annuel et dans des conditions éxperimentales. Thesis at the University of Montpellier (Languedoc); 28.05.1979.

ENGELHARDT, M., DESCHLER, B., MÜLLER, C.I. and LÜBBERT, M. (2003). Plastizität adulter Stammzellen: Wunschtraum oder Realität. Dt. Ärzteblatt 100: A3236-A3244.

FASTA (2003). http://www.ncbi.nlm.nih.gov/BLAST/fasta.html; INTERNET

FELDMAN, B., POUEYMIROU, W., PAPAIOANNOU, V.E., DECHIRA, T.M. and GOLDFARB, M. (1995). Requirement of FGF-4 for postimplantation mouse development. Science 267: 246-249.

FELSENSTEIN, J. (1993). PHYLIP, ver. 3.5. University of Washington, Seattle.

FERRARI, G., CUSELLA-DEANGElis, G., COLETTA, M., PAOlUCCI, E., STOMAIUOLO, A., COSSU, G. and MAVILLIO, F. (1998). Muscle regeneration by bone marrow-derived myogenic progenitors. Science 279: 1528-1530.

GAMULIN, V., MÜLLER, I.M. and MÜLLER, W.E.G. (2000). Sponge proteins are more similar to those of Homo sapiens than to Caenorhabditis elegans. Biol. J. Lin. Soc. 71: 821-828.

GAUDET, J., VANDERELST, I. and SPENCE, A. (1996). Post-translational regulation of sex determination in Caenorhabditis elegans. widespread expression of the sexdetermining gene fem-1 in both sexes. Mol. Cell Biol. 7: 1107-1121.

GREBENJUK, V.A., KUUSKSALU. A., KELVE. M., SCHÜTZE. J., SCHRÖDER. H.C. and MÜLLER, W.E.G. (2002). Induction of (2'-5')oligoadenylate synthetase in the marine sponges Suberites domuncula and Geodia cydonium by the bacterial endotoxin lipopolysaccharide. Eur. J. Biochem. 269: 1382-1392.

HANKS, S.K. and QUINN, A.M. (1991). Protein kinase catalytic domain sequence database: identification of conserved features of primary structure and classification of family members. Meth. Enzymol. 200A: 38-62.

HARDIE, G. and HANKS, S. (1995). The Protein Kinase FactsBook: Protein-tyrosine Kinases. (London, Academic Press)

HODGKIN, J. (1986). Sex determination in the nematode $C$. elegans. analysis of the TRA-3 suppressors and characterization of the FEMgenes. Genetics 114: 15-52.

ISREC-SERVER (2003) Distributed by INTERNET; http://www.isrec.isb-sib.ch/cgi-bin/ PFSCAN_form_parser.

JIANG, Y., JAHAGIRDAR, B.N., REINHARDT, R.L., SCHWARTZ, R.E., KEENE, C.D., ORLIZ-GONZALES, X.R., REYES, M., LENVIK, T., LUND, T., BLACKSTAD, M., DU, J., ALDRICH, S., LISBERG, A., LOW, W.C., LARGAESPADA, D.A. and VERFAILLIE, C.M. (2002). Pluripotency of mesenchymal stem cells derived from adult marrow. Nature 418: 41-49.

JOHNSTON, G. (1842). A History of British Sponges and Lithophytes. (Edinburgh: WH Lizars).

KIMBLE, J., EDGAR, L. and HIRSH, D. (1984). Specification of male development in Caenorhabditis elegans: the fem genes. Dev. Biol. 105: 234-239.

KING, N. and CARROLL, S.B. (2001) A receptor tyrosine kinase from choanoflagellates: molecular insights into early animal evolution. Proc. Natl. Acad. Sci. U.S.A. 98: 15032-15037.

KOVÁCS, P., CSABA, G. and BALOGH, G. (1982). Detection of different functional states of the cellular nucleus with the new trichrome staining technique. Acta Histochem. 71: 73-75.

KOZIOL, C., BOROJEVIC, R., STEFFEN, R. and MÜLLER, W.E.G. (1998). Sponges (Porifera) model systems to study the shift from immortal- to senescent somatic cells: the telomerase activity in somatic cells. Mech. Ageing Develop. 100: 107-120.

KRAKOW, D., SEBALD, E., KING, L.M. and COHN, D.H. (2001). Identification of human FEM1A, the ortholog of a $C$. elegans sex-differentiation gene. Gene 279: 213-219.

KRASKO, A., BATEL, R., SCHRÖDER, H.C., MÜLLER, I.M. and MÜLLER, W.E.G. (2000). Expression of silicatein and collagen genes in the marine sponge Suberites domuncula is controlled by silicate and myotrophin. Eur. J. Biochem. 267: 48784887.

KRUSE, M., MÜLLER, I.M. and MÜLLER, W.E.G. (1997). Early evolution of metazoan serine/threonine- and tyrosine kinases: identification of selected kinases in marine sponges. Mol. Biol. Evol. 14: 1326-1334.

LAEMMLI, U. K. (1970). Cleavage of structural proteins during the assembly of the head of bacteriophage T4. Nature 227: 680-685

LEYS, S.P. (2003). Comparative study of spiculogenesis in demosponge and hexactinellid larvae. Microsc. Res. Tech. 62: 300-311.
MEDINA, M., COLLINS, A.G., SILBERMAN, J.D. and SOGIN, M.L. (2001). Evaluating hypotheses of basal animal phylogeny using complete sequences of large and small subunit rRNA. Proc. Natl. Acad. Sci. USA 98: 9707-9712.

MÜLLER, W.E.G. (1982). Cell membranes in sponges. Intern. Rev. Cytol. 77: 129181.

MÜLLER, W.E.G. (2001). How was metazoan threshold crossed: the hypothetical Urmetazoa. Comp. Biochem. Physiol. [A]129: 433-460.

MÜLLER, W.E.G. and SCHÄCKE, H. (1996). Characterization of the receptor protein-tyrosine kinase gene from the marine sponge Geodia cydonium. Progr. Molec. Subcell. Biol. 17: 183-208.

MÜLLER, W.E.G., DIEHL-SEIFERT, B., GRAMZOW, M., FRIESE, U., RENNEISEN, K. and SCHRÖDER, H.C. (1988). Interrelation between extracellular adhesion proteins and extracellular matrix in reaggregation of dissociated sponge cells. Int. Rev. Cytol. 111: 211-229.

MÜLLER, W.E.G., KRUSE, M., KOZIOL, C. and LEYS, S.P. (1998). Evolution of early Metazoa: Phylogenetic status of the Hexactinellida within the phylum of Porifera [sponges]. Progr. Molec. Subcell. Biol. 21: 141-156.

MÜLLER, W.E.G., SCHRÖDER, H.C., SKOROKHOD, A., BÜNZ, C., MÜLLER, I.M. and GREBENJUK, V.A. (2001). Contribution of sponge genes to unravel the genome of the hypothetical ancestor of Metazoa (Urmetazoa). Gene276: 161173.

MÜLLER, W.E.G., KORZHEV, M., LE PENNEC, G., MÜLLER, I.M. and SCHRÖDER, H.C. (2003a). Origin of metazoan stem cell system in sponges: first approach to establish the model (Suberites domuncula). Biomol. Eng. 20: 369-379.

MÜLLER, W.E.G., WIENS, M., MÜLLER, I.M. and SCHRÖDER, H.C. (2003b). The chemokine networks in sponges: potential roles in morphogenesis, immunity and stem cell formation. Progress Molec. Subcell. Biol. 34: 103-143.

MÜLLER, W.E.G., WIENS, M., ADELL, T., GAMULIN, V., SCHRÖDER, H.C. and MÜLLER, I.M. (2004). The bauplan of the Urmetazoa: The basis of the genetic complexity of Metazoa using the siliceous sponges [Porifera] as living fossils. Int. Rev. Cytol. 235; in press.

NICHOLAS, K.B. and NICHOLAS, H.B. JR. (1997). GeneDoc: A tool for editing and annotating multiple sequence alignments. Version 1.1.004. Distributed by the author; cris.com/ ketchup/genedoc.shtml; INTERNET.

OLIVI, G. (1792). Zoologia Adriatica ossia catalogo regionato degli animali del golfo e delle lagune di Venezia. (Bassano) 1-32.

ONO, K., SUGA, H., IWABE, N., KUMA, K. and MIYATA, T. (1999). Multiple protein tyrosine phosphatases in sponges and explosive gene duplication in the early evolution of animals before the parazoan-eumetazoan split. J. Mol. Evol. 48: 654-662.

ORNITZ, D.M. and ITOH, N. (2001). Fibroblast growth factors. Genome Biol. 2, 1-12.

PALLAS, P.S. (1766). Elenchus Zoophytorum. (Hague, Petrum van Cleef).

PANCER, Z., KRUSE, M., SCHÄCKE, H., SCHEFFER, U., STEFFEN, R., KOVÁCS, P. and MÜLLER, W.E.G. (1996). Polymorphism in the immunoglobulin-like domains of the receptor tyrosine kinase from the sponge Geodia cydonium. Cell Adhes. Commun. 4: 327-339.

PAULUS, W. (1989). Ultrastructural investigation of spermatogenesis in Spongilla lacustris and Ephydatia fluviatilis (Porifera, Spongillidae). Zoomorphology 109: 123-130.

PC/GENE (1995). Data Banks CD-ROM; Release 14.0. IntelliGenetics, Inc. Mountain View, CA.

PEROVIC, S., SCHRÖDER, H.C., SUDEK, S., GREBENJUK, V.A., BATEL, R., STIFANIC, M., MÜLLER, I.M. and MÜLLER, W.E.G. (2003). Expression of one sponge Iroquois homeobox gene in primmorphs from Suberites domuncula during canal formation. Evol. Dev. 5: 240-250.

POLAK, J.M. and MCGEE, J.D. (1998). In situ Hybridization (Oxford, Oxford University Press).

RAO, J. and ARGOS, P. (1986). A conformational preference parameter to predict helices in integral membrane proteins. Biochem. Biophys. Acta. 869: 197-214.

REINKE, V., SMITH, H.E., NANCE, J., WANG, J., VAN DOREN, C., BEGLEY, R., JONES, S.J.M., DAVIS, E.B., SCHERER, S., WARD, S. and KIM, S.K. (2000). A global profile of germline gene expression in C. elegans. Mol. Cel/6: 605-616.

ROMEIS, B. (1989). Mikroskopische Technik. München; Urban/Schwarzenberg.

SARÀ, M. (1992). Porifera. In Reproduction Biology of Invertebrates; vol. VISexual differentiation and behaviour]. K.G. Adiyodi and R.G. Adiyodi, eds., pp. 1-29. Oxford, IBH Publ. Comp., New Delhi. 
SCHÄCKE, H., SCHRÖDER, H.C., GAMULIN, V., RINKEVICH, B., MÜLLER, I.M. and MÜLLER, W.E.G. (1994). Molecular cloning of a tyrosine kinase gene from the marine sponge Geodia cydoniumr a new member belonging to the receptor tyrosine kinase class II family. Mol. Membr. Biol. 11: 101-107.

SCHRÖDER, H.C., PEROVIC-OTTSTADT, S., WIENS, M., BATEL, R., MÜLLER, I.M. and MÜLLER, W.E.G. (2004). Differentiation capacity of the epithelial cells in the sponge Suberites domuncula. Cell \& Tissue Res. 316: 271-280.

SCHÜTZE, J., KRASKO, A., DIEHL-SEIFERT, B. and MÜLLER, W.E.G. (2001). Cloning and expression of the putative aggregation factor from the marine sponge Geodia cydonium. J. Cell Sci. 114: 3189-3198.

SCHWEITZER, B. and PHILIPPSEN, P. (1992). NPK1, a nonessential protein kinase gene in Saccharomyces cerevisiaewith similarity to Aspergillus nidulansnimA. Mol. Gen. Genet. 234: 164-167.

SIMPSON, T.L. (1984). The Cell Biology of Sponges. New York: Springer-Verlag.

SPENCE, A.M., COULSON, A. and HODGKIN, J. (1990). The product of fem-1, a nematode sex-determining gene, contains a motiffound in cell cycle control proteins and receptors for cell-cell interactions. Cel/60: 981-990.

SUGA, H., KATOH, K. and MIYATA, T. (2001). Sponge homologs of vertebrate protein tyrosine kinases and frequent domain shufflings in the early evolution of animals before the parazoan-eumetazoan split. Gene 280: 195-201.

THOMPSON, J.D., HIGGINS, D.G. and GIBSON, T.J. (1994). CLUSTAL W: improving the sensitivity of progressive multiple sequence alignment through sequence weighting, positions-specific gap penalties and weight matrix choice. Nucleic Acids Res. 22: 4673-4680.
VACELET, J. (1979). Quelque stades de la réproduction sexuée d'une éponge sphinctozoaire actuelle. In Biologie des Spongiaires. C. Lévi and N. Boury-Esnault, eds. (Paris, Colloq Internat CNRS) 291: 95-101.

VENTURA-HOLMAN, T., LU, D., SI, X., IZEVBIGIE, E.B. and MAHER, J.F. (2003). The Fem 1c genes: conserved members of the Fem1gene family in vertebrates. Gene 314: 133-139.

VENTURA-HOLMAN, T., SELDIN, M.F., LI, W. and MAHER, J.F. (1998). The murine fem1 gene family: homologs of the Caenorhabditis elegans sex-determination protein FEM-1. Genomics 54: 221-230.

WILKIE, A.O.M., MORRISS-KAY, G.M., JONES, E.Y. and HEATH, J.K. (1995). Function of fibroblast growth factors and their receptors. Curr. Biol. 5: 500-507.

WIMMER, W., PEROVIC, S., KRUSE, M., KRASKO, A., BATEL, R. and MÜLLER, W.E.G. (1999). Origin of the integrin-mediated signal transduction: functional studies with cell cultures from the sponge Suberites domuncula. Eur. J. Biochem. 178: 156-165.

WITTE, U. and BARTHEL, D. (1994). Reproductive cycle and oogenesis of Halichondria panicea (Pallas) in Kiel bight. In Sponges in Time and Space, R. van Soest and A.A. Balkema, eds., pp. 297-305. Rotterdam, Brookfield.

Received: March 2004

Reviewed by Referees: April 2004

Modified by Authors and Accepted for Publication: April 2004 